\title{
Adult Pineocytoma
}

National Cancer Institute

\section{Source}

National Cancer Institute. Adult Pineocytoma. NCI Thesaurus. Code C8291.

A pineocytoma occurring in adults. 